\title{
Polymerase chain reaction assay for the detection of Helicobacter pylori in gastric biopsy specimens: comparison with culture, rapid urease test, and histopathological tests
}

\author{
R Fabre, I Sobhani, P Laurent-Puig, N Hedef, N Yazigi, C Vissuzaine, I Rodde, F Potet, \\ $M$ Mignon, J P Etienne, $M$ Braquet
}

\begin{abstract}
Ulcer recurrence is probably related to residual Helicobacter pylori (H pylori). Histological examination and culture are considered to be the most specific tests. CLO test is a rapid but less specific test, which is usually used as an alternative test to culture. The aim of this study was to investigate the efficiency of a simplified polymerase chain reaction (PCR) assay as a procedure for the diagnosis of gastric $H$ pylori infection of patients. Biopsy specimens were obtained from antral mucosa of 58 patients at endoscopy and submitted to four tests for detection of $H$ pylori. The bacteria were found in $53 \%$, $43 \%, 48 \%$, and $50 \%$ of patients according to the results of PCR, CLO test, culture, and histological examination. Twenty three patients had both negative histology and negative culture and PCR was negative in all of these. Thirteen patients were not classified because only histology or culture was positive and 10 of these had a positive PCR test. When the diagnosis of $\boldsymbol{H}$ pylori was established by agreement with both histology and culture or three positive tests out of four, 29 patients were $H$ pylori positive ( 28 having had three positive tests and one displaying positive histology and culture), and 26 were negative, and three undetermined. PCR proved the most sensitive and specific test. These results suggest the simplified PCR assay may be a valuable test for the detection of $\boldsymbol{H}$ pylori.

(Gut 1994; 35: 905-908)
\end{abstract}

Helicobacter pylori ( $H$ pylori) is a microaerophilic bacterium initially found in the gastric antrum of patients with peptic ulcer disease. ${ }^{1}$ As a result, $H$ pylori is now believed to have an aetiological role in gastritis as well as in peptic ulcer disease. Several recent studies showed that it may be associated with duodenal ulcer relapse $\mathrm{e}^{2-4}$ and that eradication treatment using antibiotics may significantly decrease the prevalence of recurrence in duodenal ulcer patients. ${ }^{2-4}$

Up to now, the most specific way of detecting $H$ pylori in tissue is a combination of culture ${ }^{5}$ and histological staining ${ }^{6}$ of mucosal biopsy specimens obtained by endoscopy. This procedure is not wholly satisfactory, however, because (a) organisms resembling $H$ pylori can be detected by histological examination as false positive ${ }^{7}$ and (b) culture is both time consuming and less sensitive than histological examination.

Biopsy urease test has been developed as a rapid technique that is combined with histological examination. Unfortunately, this test is somewhat less sensitive and less specific than culture. ${ }^{8}$ Polymerase chain reaction (PCR) assay has been shown to be a valuable method for detection of various micro-organisms including $H$ pylori. Several PCR assays for $H$ pylori have been already described ${ }^{9-11}$ but none has been compared with the other classic tests in clinical studies.

The aim of this study was to investigate the efficiency of a modified Valentine's PCR assay as a procedure for the diagnosis of gastric $H$ pylori infection in patients.

\section{Patients and methods}

\section{PATIENTS}

Fifty eight consecutive patients (25 male, 33 female; mean age: 52 years; range 23 to 87 ) attending two endoscopy units (Bicêtre and Bichat hospitals) for examination of the upper gastrointestinal tract were included in this study. Patients taking antibiotics, patients with a bleeding ulcer or an acute haemorrhage from other sites in the upper gastrointestinal tract, and patients with carcinoma or with surgery of the stomach were excluded. All patients gave informed consent to the biopsies.

\section{ENDOSCOPY}

During the endoscopy using the Olympus GIF XQ20 gastroscope, a total of four biopsy specimens were taken from the gastric antrum within $5 \mathrm{~cm}$ from the pyloric channel for histological, microbiological examination, rapid urease test, and PCR assay. The macroscopical examination showed normal mucosa in 44 patients, gastric ulcer in two, and duodenal ulcer in 12 .

\section{RAPID UREASE TEST}

The biopsy specimen was placed in a CLO test (Tri-Med Specialties, Lenexa, KS). CLO test detects the urease enzyme of $H$ pylori in gastric mucosal biopsy specimens. It is a sealed plastic slide holding an agar gel, which contains urea 


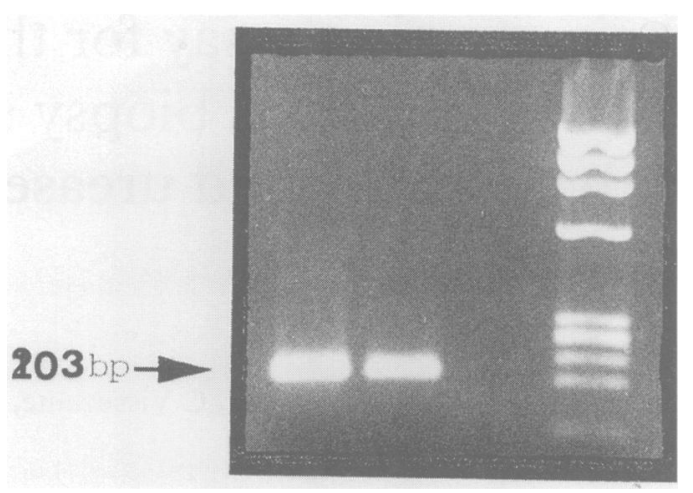

Agarose gel stained with ethidium bromide and photographed under ultra violet light showing a specific band from Helicobacter pylori lane 1: PCR product of 203 bp from antral gastric biopsy specimen of patient no 50, in lane 2 PCR positive control obtained from culture of $\mathrm{H}$ pylori, in lane 3 a PCR negative control, and in lane 4 the size marker.

and phenol red ( $\mathrm{pH}$ indicator). If urease enzyme of $H$ pylori is present in the specimen, the resulting degradation of urea causes the $\mathrm{pH}$ to rise and the colour of the gel turns from yellow to a bright magenta colour. The test, in this study, was considered as positive for the urease activity of $H$ pylori when the solution changed colour within 30 minutes.

\section{CULTURE}

The biopsy specimens were immediately immersed in a transport medium Portagerm (BioMérieux, Marcy-l'Etoile, France) and delivered to BioInova Laboratories within six hours. Biopsy specimens were aseptically dissected with a scalpel blade in $0.5 \mathrm{ml}$ of liquid peptone medium. Then $0.5 \mathrm{ml}$ of this medium was spread on Pylori gelose (BioMérieux) specific for $H$ pylori, and incubated at $37^{\circ} \mathrm{C}$ in a Campijar (Bio-Merieux) that gave microaerophilic conditions. Gelose plates were incubated until colonies were seen. The culture was considered negative if a colony did not develop within seven days.

As soon as a colony grew, identification of $H$ pylori was carried out by Gram coloration and by biochemical tests. When colonies were Gram negative and showed positivity on biochemical tests, curved micro-organisms were identified as $H$ pylori. After isolation, strains were frozen in liquid peptone medium supplemented with 25 per cent glycerol.

\section{HISTOLOGICAL EXAMINATION}

An antral biopsy specimen for each patient was fixed in formol solution for 24 hours, dehydrated, and embedded in paraffin wax. Sections were cut and stained with haematoxylin-eosin-safran and giemsa. The presence on the mucosal surface of curved shaped rod micro-organisms resembling $H$ pylori that stained with haematoxylin-eosin-safran or Giemsa was considered as positive.

\section{PCR ASSAY}

Primers - PCR was carried out with two primers CAM 2 and CAM 4 described by
Valentine et al. ${ }^{9}$ These primers have been defined from $1.9 \mathrm{~Kb}$ chromosomal DNA proble of $H$ pylori. Specificity of this probe has been extensively tested by Valentine among 19 $H$ pylori strains and 306 non- $H$ pylori strains. These two primers, CAM 2 (5'CAT CTT GTT AGA GGG ATT GG 3') and CAM 4 (5' TAA CAA ACCGAT AAT GGC GC 3') were synthesised using a Biosystem Applied DNA synthesizer.

Specimen treatment - frozen biopsy specimens were thawed in $150 \mu$ of lysis medium (TRIS-Hcl $1 \mathrm{M}, \mathrm{pH} 8.3$ EDTA $0.5 \mathrm{M}$, Nonidet 0.5 per cent, proteinase $K$ $0.2 \mathrm{mg} / \mathrm{ml}$ ). They were digested by stirring for eight hours in $2 \mathrm{ml}$ cryotubes. After centrifugation at $3500 \mathrm{rpm}$, supernatants were collected and proteinase $\mathrm{K}$ inactivated by $95^{\circ} \mathrm{C} \times 15$ minutes.

$P C R$ conditions $-10 \mu \mathrm{l}$ of supernatant from biopsy specimen digestion were dispensed in $90 \mu \mathrm{l}$ of PCR medium (TRIS-HCl $10 \mathrm{mM}$, Mg C12 1.5 mM, KCl $50 \mathrm{mM}$, gelatine $0 \cdot 1$ per cent, 4 dNTPs $5 \mathrm{mM}$ each, $1.25 \mathrm{U}$ of Taq polymerase with primers CAM 2 and CAM 4, $0.5 \mathrm{mM}$ each. Forty cycles were performed each cycle consisting of one minute denaturation step at $95^{\circ} \mathrm{C}, 30$ second annealing step at $42^{\circ} \mathrm{C}$, and one minute elongation step at $72^{\circ} \mathrm{C}$.

Electrophoresis of PCR products $-8 \mu \mathrm{l}$ of PCR products were mixed with $3 \mu$ l of bromophenol blue. A 1.5 per cent agarose gel in TRIS borate EDTA buffer was loaded with $10 \mu l$ of the mixture. Gel was stained with ethidium bromide and photographed under ultraviolet light illumination.

PCR assay was considered positive when a 210 pair base product, which was equivalent to the fragment described by Valentine, was found after amplication (Figure).

CLO test, histological examination, culture, and PCR results were blinded to each other.

\section{Results}

INDIVIDUAL RESULTS (TABLE I)

According to criteria described above $H$ pylori was identified in $53 \%, 43 \%, 48 \%, 50 \%$, of patients by PCR, CLO test, culture and histological tests, respectively.

PCR ASSAY $V$ COMBINATION OF CULTURE AND HISTOLOGICAL EXAMINATION

When infection was diagnosed by positive culture and histological examination, 23 patients were considered as $H$ pylori negative, 22 as positive and 13 unclassified (six $H$ pylori culture positive and seven positive by histological examination). PCR assay was negative in $23 \mathrm{H}$ pylori negative patients, positive in 21 of $22 \mathrm{H}$ pylori positive patients. It was positive in 10 of 13 unclassified patients (six with culture positive and four with histologically positive tests). Sensitivity and specificity values for PCR assay were $95 \%$ and $100 \%$ respectively. 
TABLE I Individual results of polymerase chain reaction assay

\begin{tabular}{lllll}
\hline Patient $^{*}$ & Histology & Culture & PCR assay & CLO test \\
\hline 1 to $21(21)$ & - & - & - & - \\
22 to $37(16)$ & + & + & + & + \\
38 to $39(2)$ & - & + & + & + \\
40 to $42(3)$ & - & + & + & - \\
43 to $45(3)$ & - & + & + & + \\
46 to $49(4)$ & + & + & + & - \\
50 to $52(3)$ & + & + & - & - \\
53 to $57(5)$ & + & $28 / 58(48)$ & $31 / 58(53)$ & $25 / 58(43)$ \\
$58(1)$ & $29 / 58(50)$ & & &
\end{tabular}

${ }^{\star}$ Rank (number); all tests were perfomed on the gastric mucosa biopsy specimens.

\section{H PYLORI STATE ACCORDING TO THREE} CONCORDANT TESTS OR TO THE AGREEMENT OF HISTOLOGICAL EXAMINATION AND CULTURE To define the $H$ pylori infection state of patients, we took into account the results of the four tests (CLO test, histological examination, culture, PCR). The infection state was considered as positive or negative if at least three of four tests agreed. In this respect 54 patients could be classified as 28 positive and 26 negative. Among the remaining four patients who were positive or negative for only two tests (no 43-45 and 58), one (no 58) has been considered $H$ pylori positive according to the standard criteria and three (no 43-45) were not included in the following analysis (Table I).

Specificity, sensitivity, positive predictive value, negative predictive values of each test have been determined according to the $H$ pylori infection state (Table II). PCR assay was the most sensitive and specific method compared with culture, histological examination, and urease CLO test.

\section{Discussion}

This study assessed four biological diagnostic methods for $H$ pylori detection in gastric biopsy specimens. The results of this study showed that PCR assay was a sensitive method for the diagnosis of gastric infection by $H$ pylori as PCR could detect $H$ pylori in $53 \%$ of our patients. When only patients with positive histological tests and positive culture were deemed to be infected, the specificity and sensitivity of PCR assay were 1 and 0.95 , respectively. PCR assay failed to detect $H$ pylori in only one of 22 patients (no 58) whereas it could be shown by culture and histological examination. The PCR assay performed on the $H$ Pylori isolates from the culture of the same patient showed a specific band of $210 \mathrm{bp}$. This discrepancy between the PCR assay result from biopsy specimens and culture might be explained by the absence of micro-organisms the sample used for PCR assay, or by the presence in vivo of a Taq

TABLE II Specificity, sensitivity, positive predictive value (PPV), and negative predictive value (NPV) of each test

\begin{tabular}{lllll}
\hline & Urease test & Histological examination & Culture & $P C R$ \\
\hline Sensitivity & 0.79 & 0.90 & 0.86 & 0.96 \\
Specificity & 0.92 & 0.88 & 1 & 1 \\
PPV & 0.92 & 0.90 & 1 & 1 \\
PNV & 0.80 & 0.88 & 0.86 & 0.96 \\
\hline
\end{tabular}

polymerase inhibitor. In contrast PCR assay showed specific amplification in four negative culture patients (no 46-49; Table I). Interestingly the CLO test as well as histological examination were positive in these patients suggesting that, even in routine examination PCR assay is more sensitive than culture.

The requirement of positive culture and positive histological test for diagnosis of infection failed to classify 13 of 58 patients. In fact, six of them could be considered as $H$ pylori positive on the basis of $H$ pylori isolates from culture. In all cases the PCR assay was positive. Furthermore in four of the seven remaining unclassified patients the PCR assay was positive. Interestingly the CLO test was also positive in these patients. As only $78 \%$ of patients could be classified according to the requirement of both positive histological test and culture, we would suggest that to define as $H$ pylori positive or negative, all patients need at least three positive or negative tests, respectively. This procedure decreased the number of unclassified patients to three $(5 \%)$. This result was impaired by the sensitivity of CLO test (sen $=0 \cdot 79$ ), which is known as a very rapid and inexpensive test. The rate of a positive CLO test in this study is lower than that seen in previous studies. This might be explained by an incubation period ( 30 minutes) that was too short. Furthermore, the histological examination was less specific $(\mathrm{sp}=0.88)$ than culture $(\mathrm{sp}=1)$. More interestingly, PCR assay showed a sensitivity of 0.96 and a specficity of 1 suggesting that it could be considered as a reference test.

$H$ pylori is related to duodenal ulcer relapse and detection of residual $H$ pylori after antibiotics is probably useful in therapeutic trials. In this respect physicians need a reliable test. As CLO test is rapid but not sensitive, histological examination useful but not specific, culture somewhat less sensitive than histological examination, we would suggest that PCR assay should be considered as a reference test. The PCR assay that we used had been dramatically simplified compared with Valentine's test. ${ }^{9}$ DNA extraction by phenol/ chloroform and hybridisation by radioactive probes have been suppressed and the time and costs of this procedure were consequently reduced. It is important to note, however, that because of its high sensitivity, the PCR method can detect $H$ pylori even if present in only few numbers. So, contamination of materials even by dead micro-organisms may give a false positive result by PCR test. Thus physicians must pay particular attention to the disinfection of the endoscope and forceps and also when the biopsy specimens are handled in the endoscopy room.

The PCR test can be especially useful during and after treatment for eradication of $H$ pylori. The alternative test to detect $H$ pylori after eradication is the urease breath test, which is based on the in vivo urease activity of microorganisms. As far as we know these two procedures have not been compared with each other. Comparison between these two tests needs further study. 


\section{Conclusion}

In this study we showed that the PCR procedure is a valuable technique for detection of $H$ pylori and that its high sensitivity and specificity should make it a reference test for the detection of $H$ pylori. Furthermore, this simplified PCR assay can be used routinely by physicians in therapeutic trials, in particular after an eradication course with antibiotics.

1 Marshall BJ, Warren JR. Unidentified curved bacilli in the stomach of patients with gastritis and peptic ulceration. Lancet 1984; i: 1311-5.

2 Rauws EAJ, Tytgat GNJ. Cure of duodenal ulcer associated with eradication of Helicobacter pylori. Lancet 1990; 335: 1233-5.

3 Coghlan JG, Gilligan D, Humphries H, McKenna D Dooley C, Sweeney E, et al. Campylobacter pylori and Dooley C, Sweeney E, et al. Campylobacter pylori and recurrence of duodenal ulcers

4 Marshall BJ, Goodwin CS, Warren JR, Murray R, Blincow E, Blackgourn SJ, et al. Prospective double blind trial of duodenal ulcer relapse after eradication of Campylobacter pylori Lancet 1988; ii: 1437-42.
5 Goodwin CS, Blincow ED, Warren JR, Waters TE, Sanderson CR, Easton L. Evaluation of cultural techniques for isolating Campylobacter pyloridis from endoscopic biopsies of gastric mucosa. 7 Clin Pathol 1985; 38: $1127-31$.

6 Peterson WL, Lee EL, Feldman M. Relationship between Campylobacter pylori and gastritis in healthy humans after placebo or indomethacin. Gastroenterology 1988; 95: after place

7 Dye KR, Marshall BJ, Frierson HF, Guerrant RL, McCallum RW. Ultrastructure of another spiral organism associated with human gastritis. Dig Dis Sci 1989; 34: 1787-91.

8 McNulty CAM, Dent JC, Uff JS, Gear MWL, Wilkinson SP. Detection of Campylobacter pylori by the biopsy urease test: an assessment in 1445 patients. Gut $1989 ; 30$ : 1058-62.

9 Valentine JL, Athur RR, Mobley HLT, Dick JD. Detection of Helicobacter pylori by using the polymerase chain reaction. f Clin Microbiol 1991; 29: 689-95.

10 Clayton CL, Kleanthous $H$, Tabaqchali S. Detection and identification of Helicobacter pylori by the and identification of Helicobacter pylori by the 515-6.

11 Hoshina S, Kahn SH, Jiang W, Green PH, Neu HC, Chin $\mathrm{N}$, et al. Direct detection and amplification of Helicobacter pylori ribosomal $16 \mathrm{~S}$ gene segments from gastric endoscopic biopsies. Diagn Microbiol Infect Dis 1990; 13: 473-9. 